\title{
,nux \\ Effect of Land-Use Change on Runoff in Hyrcania
}

\author{
Naser Ahmadi-Sani ${ }^{1}$, Lida Razaghnia ${ }^{2}$ and Timo Pukkala ${ }^{3, *(1)}$ \\ 1 Faculty of Agriculture and Natural Resources, Mahabad Branch, Islamic Azad University, \\ Mahabad 59135-433, Iran; n_sani@iau-mahabad.ac.ir \\ 2 Department of Watershed Management, Haraz University, Amol 46178-78737, Iran; li.razaghnia@gmail.com \\ 3 School of Forest Sciences, University of Eastern Finland, 80100 Joensuu, Finland \\ * Correspondence: timo.pukkala@uef.fi; Tel.: +358-40-511-2089
}

Citation: Ahmadi-Sani, N.; Razaghnia, L.; Pukkala, T. Effect of Land-Use Change on Runoff in

Hyrcania. Land 2022, 11, 220. https://doi.org/10.3390/land 11020220

Academic Editor: Ilan Stavi

Received: 8 January 2022

Accepted: 30 January 2022

Published: 31 January 2022

Publisher's Note: MDPI stays neutral with regard to jurisdictional claims in published maps and institutional affiliations.

Copyright: (c) 2022 by the authors. Licensee MDPI, Basel, Switzerland. This article is an open access article distributed under the terms and conditions of the Creative Commons Attribution (CC BY) license (https:// creativecommons.org/licenses/by/ $4.0 /)$.

\begin{abstract}
Population growth and human activities have resulted in drastic changes in land use in many areas of the world, including the Hyrcania region in northern Iran. Land-use changes affect the hydrological processes of water basins. This study evaluated the effect of land-use changes on runoff over 15 years in the Haraz River basin located in Hyrcania using remote sensing data and GIS analyses. The annual precipitation of the region is $66.5 \mathrm{~cm}$. Two Landsat images were used to develop land-use maps for 1996 and 2011. Original image features, their principal components, and vegetation indices were used to classify the two Landsat images into different land-use categories. Runoff was predicted from precipitation, land use, and hydrological soil groups, using the SCS-CN model (the "curve number" approach). During the 15 years, $62.4 \%$ of the area remained unchanged and $37.6 \%$ had undergone a land-use change. The highest average runoffs were obtained for bare land (14.1-14.5 cm/year) and residential land (10.4-11.4 cm/year), and the lowest for dense forest $(2.5-2.6 \mathrm{~cm} /$ year) and first-grade rangeland $(2.8-3.1 \mathrm{~cm} /$ year$)$. The volume of annual runoff increased by $9 \%$ during 1996-2011 due to land-use changes. Runoff was estimated at $9.4 \%$ of precipitation in 1996, and $9.6 \%$ of precipitation in 2011. Most of the increase was related to the increased area of bare land and decreased area of rangeland. The study indicated that combined use of the SCS$\mathrm{CN}$ approach, remote sensing data, and GIS tools allow cost-effective runoff estimation, helping watershed management. The results on the effect of land-use change on runoff can be seen as a warning for land-use managers and policymakers, who should aim at stopping and reversing the current land-use trends of the Haraz River basin.
\end{abstract}

Keywords: land-use mapping; curve number method; land degradation; erosion

\section{Introduction}

Land is an essential natural resource, both for humanity, and the maintenance of all terrestrial ecosystems [1]. Increases in population density and human activities have caused increased demand for water, arable land, wood, grazing areas, and other types of resources [2,3]. Water is an indispensable resource and a key element in human livelihood and socioeconomic development [4]. As water consumption increases, water availability may become a critical factor for human activities. This makes it necessary to manage water resources for their sustainable use [3].

Precipitation is the main source of water in the world. It is unevenly distributed spatially and temporally and strongly influenced by climate and land use [5]. Precipitation and runoff are the main hydrologic components in water resources assessment [6].

Runoff is the result of interactions among climate, terrain, and land use in a water basin. Climate change may change the spatial and temporal distribution of precipitation, affecting the amount and spatial configuration of runoff. Changes in land use may alter the flow processes, which also affects runoff. Although climate change plays a key role in runoff changes, the impact of human activities cannot be ignored [7]. The impact of 
land cover and climate change on hydrology are global issues affecting the hydrological processes of river basins $[8,9]$.

The impact of vegetation on water runoff is complex. The influence of vegetation, its growth, regeneration, and succession depend on soil properties and micro-topography of the terrain, among other things [10]. The common understanding is that increasing the vegetation cover decreases surface runoff and erosion, but the relationships are not always straightforward since the effect of tree cover depends on tree species and the vertical structure of the canopy [11]. Forests have a limited capability to retain precipitation, even when the forest cover is high. This inadequacy is most apparent during extreme rainfall events [12-14]. The results of some studies have indicated that rainfall intensity was the most important factor that influenced runoff [15], and forests and other vegetation were not always capable of retaining much of the rainfall. Differences in natural and geographical conditions or the type and structure of vegetation have an impact on water interception, surface runoff, groundwater, and evaporation, which affect the spatio-temporal patterns of water cycles [10].

Land-use changes have direct effects on the hydrological processes of watersheds, which depend on land-cover characteristics [16-19]. Changes in land use in areas characterized by large and fast runoff (e.g., areas with much rain but little vegetation) have immediate impacts, while changes in areas with little rain and much vegetation have smaller and delayed impacts [20].

Studies on the relationship between changes in vegetation cover and water runoff dynamics provide information for the regulation of water resources and effective mitigation of the damage caused by land-use changes $[10,16]$. Watershed management is based on controlling the hydrological processes, mainly runoff $[5,21]$. Analyzing the long-term dynamics of runoff has practical significance since the new knowledge enhances the management and sustainable use of water resources [10].

Many hydrologic models such as HYMOD, LRHM, and TANK exist for calculating runoff [22-25]. In Iran, the "curve number method" of the Soil Conservation Service (SCS) of the United States Department of Agriculture (SCS-CN method) is the most frequently used method $[26,27]$. The runoff curve number $(\mathrm{CN})$ is the key factor of the SCS-CN method and depends on land use and land cover (LULC), soil type, and soil moisture $[16,21,28]$. Often, an area-weighted average curve number for the entire watershed is used to estimate the runoff of a watershed. This type of analysis ignores the details of the spatial variation in the watershed. A GIS tool called ArcCN-Runoff facilitates detailed and spatially explicit runoff estimation, reducing processing times and improving the efficiency of the analyses [29].

Water runoff and erosion depend on several factors, among which land use has been most studied [30]. Large-scale land-use mapping based on fieldwork is expensive and time-consuming and field mapping of past years' land uses is impossible. The use of remote sensing data may alleviate these problems because old imageries are available at a low cost. Lacking or inaccurate ground truth information is sometimes a partial hindrance to the effective use of old imageries [10].

GIS is an effective and flexible tool for analyzing and visualizing the effects of LULC [31,32]. Remote sensing provides a synoptic view and wall-to-wall data on watershed basins. The GIS environment facilitates the integration of different data sources and performs complicated spatial analyses to support decision making related to hydrological processes [33-35].

One of the recent interests in hydrologic modeling is the assessment of the effects of land-use changes on water resources. As watersheds become more influenced by human activities, they also become more active hydrologically with changing runoff components, streamflows, and flood volumes [36].

Various natural hazards such as floods, landslides, and bed erosion at riverbanks are increasingly observed in northern Iran, including the Haraz River basin with an area of 6774 square kilometers. Vegetation degradation and land-use changes are believed to be important reasons for the increased hazards. This study analyzed the effect of land-use 
change on runoff in the Haraz River basin during 15 years, using remote sensing data, GIS methods, and the ArcCN-Runoff tool. The objective was to provide useful information for regulating water resources, to reduce soil erosion and improve the management of the watershed.

\section{Materials and Methods}

\subsection{Steps of the Analysis}

The study area is a part of the Haraz River basin with an area of about 406,000 hectares, located in the Mazandaran province, North Iran (Figure 1). The dominant land-use categories are rangeland with a few subclasses, hardwood forest, farmland, horticultural land, and bare land.

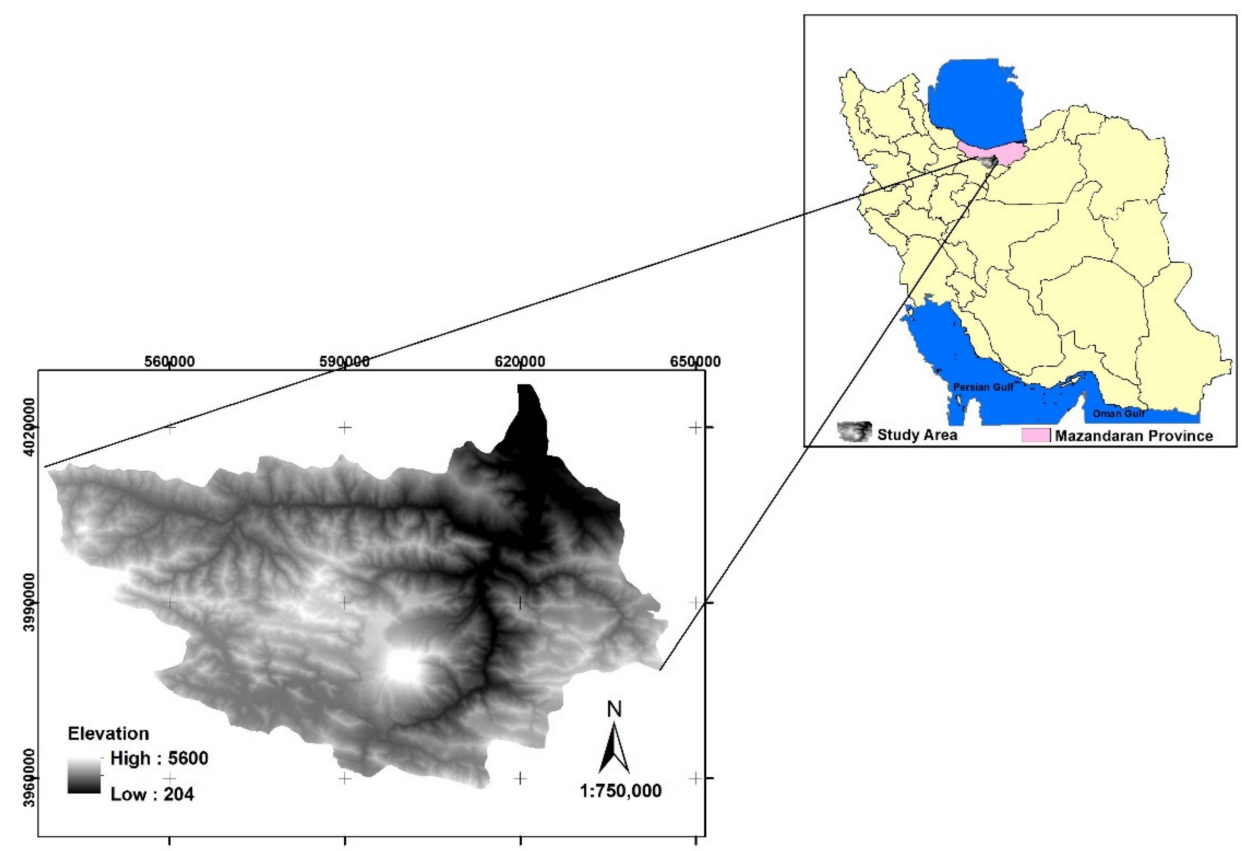

Figure 1. Location and satellite image of the study area in Iran. The lower map is a digital elevation model of the study area.

The analyses consisted of the following steps:

1. Land-use maps were developed for 1996 and 2011 using a Landsat image from these years and supervised classification.

2. A map of hydrological soil groups was developed using soil characteristics.

3. Water runoff potential was evaluated by assigning a "curve number" for different combinations of land use and hydrological soil group.

4. Information on different rain events during a year was obtained from weather stations.

5. Runoff was calculated for 1996 and 2011 by combining the land-use information (Step 1), information on hydrological soil groups (Step 2), curve numbers for different combinations of land use and hydrological soil group (Step 3), and the distribution of rain intensity classes (Step 4).

\subsection{Land-Use Classification}

Two Landsat satellite images were used for land-use mapping [16,34,37] one from the beginning (1996) and the other at the end (2011) of the analyzed 15-year period. Supervised classification with the maximum likelihood method was used. The land-use classes were: 1 bare land, 2 irrigated farming, 3 dense forests, 4 sparse forests and horticulture, 5 rangeland and dry farming, 6 first-grade range, 7 second-grade range, 8 residential land, and 9 water. First, radiometric and geometric corrections were done on the images. Various derived features such as principal components of the original channels (PC), soil-adjusted 
vegetation index (SAVI) and natural difference vegetation index (NDVI) were calculated and used in the classification along with the original bands. Before selecting the best combination of original and derived image features, training sites were chosen separately for each image (Table 1). RGB color composites, field control points and aerial photographs were used in the selection of training sites.

Table 1. Number and total area of ground truth areas used in the classification of satellite images. The classification was made for the whole Haraz River basin (677,393 ha). The results of this study were calculated for a smaller area of 406,000 ha.

\begin{tabular}{ccccc}
\hline & $\mathbf{1 9 6 6}$ & & $\mathbf{2 0 1 1}$ & \\
\hline Land-Use Class & Number & Area, ha & Number & Area, ha \\
\hline Bare land & 10 & 163 & 11 & 179 \\
Irrigated & 16 & 281 & 15 & 617 \\
farming & 16 & 278 & 18 & 252 \\
Dense forest & 11 & 82 & 10 & 137 \\
$\begin{array}{c}\text { Sparse forest } \\
\text { and horticulture }\end{array}$ & & & & 531 \\
Rangeland and & 305 & 30 & 106 \\
dry farming & 22 & 211 & 17 & 385 \\
First-grade & & & & 238 \\
range & 18 & 260 & 19 & 44 \\
$\begin{array}{c}\text { Second-grade } \\
\text { range }\end{array}$ & 17 & 80 & 16 & \\
Residential & 8 & 41 & $\mathbf{1 4 4}$ & \\
Water & 6 & & &
\end{tabular}

To remove isolated pixels and smooth the classified images, a mode filter with a $3 \times 3$ window was used. The accuracy of the classification was evaluated using the ground truth data. Land-use changes were calculated from the two classifications in the GIS environment. The chi-square statistic was used to evaluate the significance of land-use changes [38-40].

\subsection{Hydrological Classification}

A map of hydrological soil groups (HSG) was developed using soil texture. The HSG depended on soil texture as explained in [41]. The HSG indicates the rate at which water moves within the soil. The four hydrological groups used in our study (A, B, C, and D) have been described by the National Resources Conservation Service of the United States Department of Agriculture [41]. In this research, the method used to assign the HSGs was based on soil texture and adapted from Abraham et al. [42]. The HSG depended on soil texture as explained in NRCS [41] and Kumar et al. [21]. The soil texture map developed by the Iran Surveying Organization on a scale of 1:100,000 was used.

\subsection{Calculation of Runoff Potential}

The potential water runoff in various land-use categories and HSGs was evaluated by assigning a "curve number" (CN) for each combination, which is a widely used method for estimating the amount of direct runoff from a rainfall event in a particular area. The assessment of the curve numbers was based on earlier literature [43].

\subsection{Estimation of Runoff}

Various hydrological models exist to assess the quantity of direct runoff in watershed basins. These models differ in complexity and requirements for input data [21]. The "curve number" method of the Soil Conservation Service (SCS) of the United States Department of Agriculture (SCS-CN) is a commonly used approach for estimating direct surface runoff from precipitation [34]. It was used also in this study to calculate the runoff. 
Runoff estimates were derived from precipitation and the curve numbers of different combinations of hydrological soil class and land use. Information on daily precipitation was available from three weather stations (Panjab, Karehsang and Nemarestagh). Summing the available information, the following average annual distribution of different rain events was obtained:

- $5 \mathrm{~mm}$ (<10 mm): 66 times/year

- 15 mm: 10 times/year

- 25 mm: 2 times/year

- 35 mm: 1 times/year

- $45 \mathrm{~mm}: 1$ times/year

- 55 mm: 1 times/year

This resulted in total annual precipitation of $665 \mathrm{~mm}$. Water runoff was calculated separately for each rain intensity, land-use and hydrological soil group. The total runoff of certain land use was obtained from

$$
R_{\mathrm{total}}=\sum_{i=1}^{3} w_{i}\left(\sum_{j=1}^{6} n_{j} R_{i j}\right)
$$

where $R_{\text {total }}$ is total annual runoff (mm/year), $w_{i}$ is the proportion of HSG $i$ ( $i=1$ for HSG B, $i=2$ for, $C$ and $i=3$ for $\mathrm{D}), n_{j}$ is the number of rain events of intensity $j(5 \mathrm{~mm}, 15 \mathrm{~mm}$, etc.) and $R_{i j}$ is the amount of runoff in a single rain event with intensity $j$ in hydrological soil class $i$.

The SCS curve number method assumes that, for a rain event, the ratio of actual water retention of soil after runoff begins to the potential maximum retention of soil is equal to the ratio of direct runoff to precipitation. This assumption results in the following runoff equation where the curve number $(30 \leq \mathrm{CN} \leq 100)$ represents the potential maximum soil retention $(S)$ :

$$
R=\left\{\begin{array}{l}
\frac{(P-0.2 S)^{2}}{(P+0.8 S)} \quad \text { if } P>0.2 S \\
0 \quad \text { if } P \leq 0.2 S
\end{array}\right.
$$

where $R$ is the runoff in a single rain event, $P$ is the amount of rain and $S=(1000 / C N)-$ 10 inches, or $S=(25,400 / \mathrm{CN})-254 \mathrm{~mm}$ in SI units [29]. The parameter of Equation (2) (0.2) is called the initial abstraction ratio. Henceforth, the actual runoff at a certain point, expressed as $\mathrm{cm} /$ year is called runoff depth. When runoff depth is integrated over a certain area, the resulting variable is runoff volume. Runoff depths and volumes were calculated for the beginning and the end of the 15 years. Changes in the volume of runoff resulting from land-use change were calculated as the difference between 1996 and 2011.

\section{Results}

\subsection{Land-Use Change}

The accuracy of the classifications was assessed using the validation datasets $(30 \%$ of the ground truth areas). Table 2 shows the results for 130 test points taken from 144 ground truth areas of the 2011 image. The accuracy assessments showed that the overall accuracy was $87 \%$ for 1996 and $90 \%$ for 2011. The Kappa coefficient was 0.83 for 1996 and 0.88 for 2011.

Land-use maps for 1996 and 2011 (Figure 2) were used to find the changes in land use during the 15 years (Figure 3). In 1996, the most common land uses were rangeland combined with dry farming (Class 5 in Figure 2), and rangeland without farming (Classes 6 and 7). Dense forests covered 7\% and the share of bare land was 10.4\% (Table 3). By 2011, the percentage of bare land had increased to $15.4 \%$, and the share of rangeland with dry farming had increased to $62.7 \%$. The area of dense forest had decreased slightly, and the areas of rangelands without farming (Classes 6 and 7) had decreased significantly. 
Table 2. Accuracy of the classification of the 2011 image. The classes were: 1 , bare land; 2 , irrigated farming; 3 , dense forests; 4 , sparse forests and horticulture; 5 , rangeland and dry farmin; 6 , first-grade range; 7 , second-grade range; 8 , residential; 9 , water.

\begin{tabular}{ccccccccccc}
\hline Classified Land Use & $\mathbf{1}$ & $\mathbf{2}$ & $\mathbf{3}$ & $\mathbf{4}$ & $\mathbf{5}$ & $\mathbf{6}$ & $\mathbf{7}$ & $\mathbf{8}$ & $\mathbf{9}$ & Total \\
\hline 1 & 12 & 0 & 0 & 0 & 0 & 0 & 0 & 0 & 0 \\
12 \\
2 & 0 & 16 & 0 & 0 & 0 & 0 & 0 & 0 & 0 \\
3 & 0 & 0 & 18 & 3 & 0 & 0 & 0 & 0 & 0 \\
4 & 0 & 2 & 2 & 6 & 0 & 0 & 0 & 0 & 0 \\
5 & 0 & 1 & 0 & 1 & 31 & 1 & 1 & 0 & 0 & 35 \\
6 & 0 & 0 & 0 & 0 & 0 & 7 & 1 & 0 & 0 & 8 \\
7 & 0 & 0 & 0 & 0 & 0 & 0 & 8 & 1 & 0 & 9 \\
8 & 0 & 0 & 0 & 0 & 0 & 0 & 0 & 11 & 0 & 11 \\
9 & 0 & 0 & 0 & 0 & 0 & 0 & 0 & 0 & 8 \\
\hline
\end{tabular}

(a)

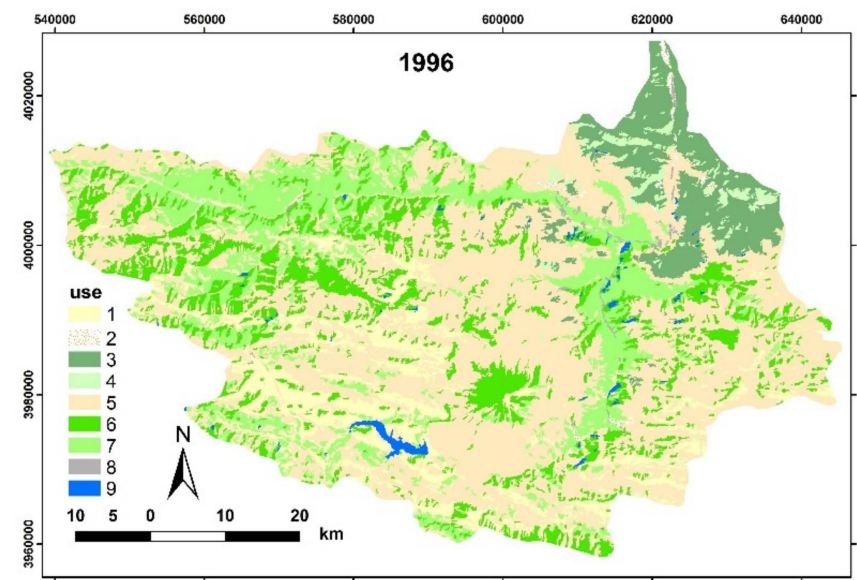

(b)

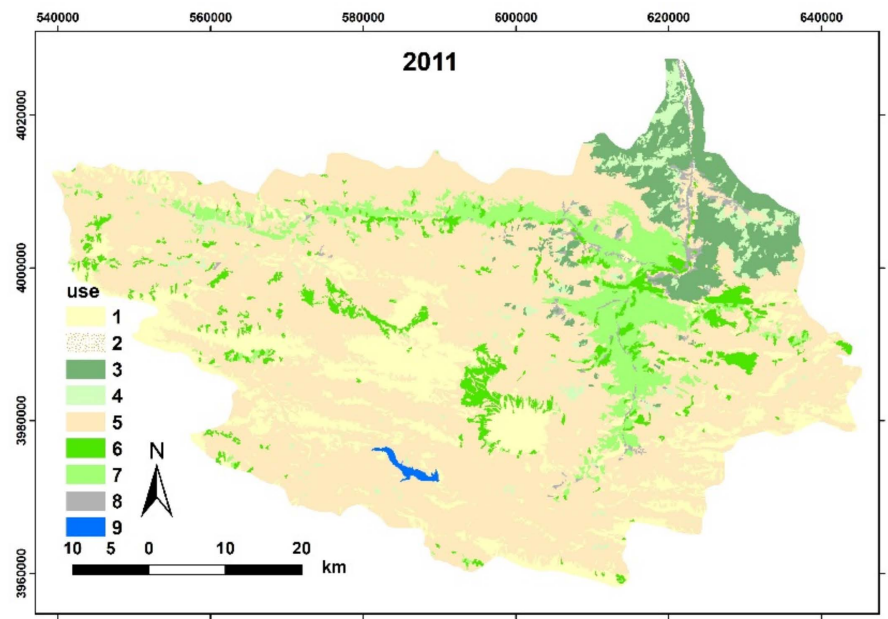

Figure 2. Land-use map of 1996 (a) and 2011 (b). The land-use classes are 1, bare land; 2, irrigated farming; 3 , dense forests; 4 , sparse forests and horticulture; 5 , rangeland and dry farming; 6 , firstgrade range; 7 , second-grade range; 8 , residential lands; 9 , water. 


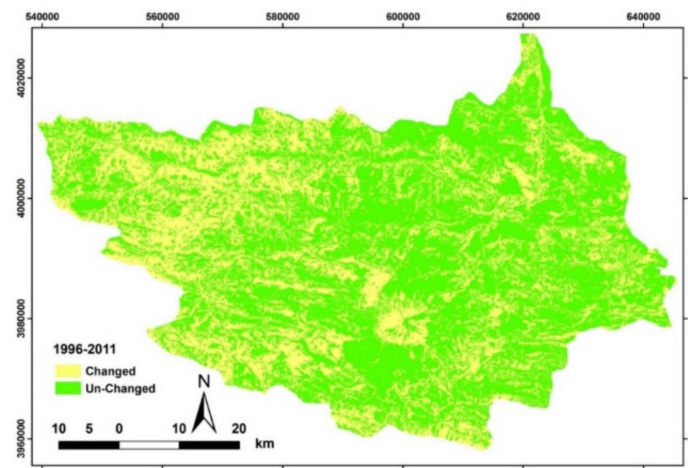

Figure 3. Areas where the land use has changed (yellow) or remained the same (green) between 1996 and 2011.

Table 3. Areas and percentages of land-use classes in 1996 and 2011.

\begin{tabular}{lccccc}
\hline Code & Land Use & \multicolumn{2}{c}{$\mathbf{1 9 9 6}$} & \multicolumn{2}{c}{$\mathbf{2 0 1 1}$} \\
& & Area (ha) & $\mathbf{\%}$ & Area (ha) & $\mathbf{\%}$ \\
\hline 1 & Bare land & 42,289 & 10.40 & 62,724 & 15.43 \\
2 & Irrigated farming & 1532 & 0.38 & 622 & 0.15 \\
3 & Dense forest & 28,535 & 7.01 & 24,551 & 6.04 \\
4 & Sparse forest and horticulture & 6188 & 1.52 & 10,007 & 2.46 \\
5 & Rangeland and dry farming & 198,367 & 48.78 & 255,144 & 62.74 \\
6 & First-grade range & 59,843 & 14.72 & 18,898 & 4.65 \\
7 & Second-grade range & 65,698 & 16.16 & 29,745 & 7.31 \\
8 & Residential & 1468 & 0.36 & 4049 & 1.00 \\
9 & Water & 2709 & 0.67 & 888 & 0.22 \\
\hline
\end{tabular}

During the 15 years, about $62 \%$ of the area remained unchanged, while land use changed in $38 \%$ of the area (Tables 4 and 5). Of these changes, about $23 \%$ was related to the conversion of first- and second-grade rangelands to each other and other uses, especially to rangeland with dry farming (17.1\%) and bare land $(4.1 \%)$. About $6 \%$ of the changes were accounted for by the conversion of rangeland/dry farming to other uses, especially bare land $(4.6 \%)$. The chi-square test showed that the changes in the areas of land-use classes were significant $(p<0.01)$.

Table 4. Area of unchanged land use between 1996 and 2011.

\begin{tabular}{ccc}
\hline Land Use & Area (ha) & Proportion (\%) \\
\hline Bare land & 26,888 & 6.61 \\
Irrigated farming & 239 & 0.06 \\
Dense forest & 22,148 & 5.45 \\
Low-dense forest and horticulture & 3313 & 0.81 \\
Rangeland and dry farming & 165,657 & 40.74 \\
First-grade range & 12,441 & 3.06 \\
Second-grade range & 21,670 & 5.34 \\
Residential & 420 & 0.10 \\
Water & 881 & 0.22 \\
\hline
\end{tabular}

\subsection{Hydrological Soil Groups}

The soil texture map showed that soils with coarse, medium, and heavy textures cover $14 \%, 39 \%$, and $47 \%$ of the total area, respectively, indicating that the area has moderate to high potential for surface runoff. The three hydrological soil groups of the region $(\mathrm{B}, \mathrm{C}$, and D) cover $15 \%$ (B), $36 \%$ (C) , and $49 \%$ (D) of the area (Table 6 ). 
Table 5. Main changes in land use between 1996 and 2011

\begin{tabular}{cccc}
\hline Land Use in 1996 & Land Use in 2011 & Area (ha) & Area (\%) \\
\hline Second-grade range & Rangeland and dry farming & 35,857 & 8.82 \\
First-grade range & Rangeland and dry farming & 33,945 & 8.35 \\
Rangeland and dry farming & Bare land & 18,801 & 4.62 \\
Bare land & Rangeland and dry farming & 15,316 & 3.77 \\
First-grade range & Bare land & 10,959 & 2.70 \\
Second-grade range & Bare land & 5788 & 1.42 \\
Rangeland and dry farming & Second-grade range & 5042 & 1.24 \\
\hline
\end{tabular}

Table 6. Proportions and curve numbers of hydrological groups B, C, and D (group A does not exist in the study area). See Table 2 for the explanation of hydrological groups.

\begin{tabular}{cccccccccc}
\hline Land Use & \multicolumn{3}{c}{$\begin{array}{c}\text { Percentage } \\
\text { 1996 }\end{array}$} & \multicolumn{3}{c}{ Percentage } & \multicolumn{3}{c}{ Curve Number } \\
& B & C & D & B & C & D & B & C & D \\
\hline Bare land & 16 & 33 & 51 & 11 & 32 & 56 & 86 & 91 & 94 \\
Irrigated farming & 46 & 30 & 24 & 63 & 19 & 19 & 75 & 82 & 86 \\
Dense forest & 14 & 32 & 54 & 13 & 29 & 58 & 60 & 73 & 79 \\
Sparse forest and horticulture & 9 & 31 & 60 & 21 & 34 & 45 & 66 & 77 & 83 \\
Range land and dry farming & 16 & 39 & 45 & 16 & 40 & 45 & 69 & 79 & 84 \\
First-grade range & 9 & 29 & 63 & 18 & 24 & 57 & 61 & 74 & 80 \\
Second-grade range & 14 & 40 & 45 & 8 & 28 & 64 & 79 & 86 & 89 \\
Residential & 32 & 24 & 43 & 19 & 27 & 54 & 85 & 90 & 92 \\
Water & 41 & 14 & 45 & 79 & 17 & 4 & 100 & 100 & 100 \\
Total & 15 & 36 & 49 & 15 & 36 & 49 & & & \\
\hline
\end{tabular}

\subsection{Curve Numbers and Runoff}

The curve numbers (Table 6) are related to the runoff potential for different land uses and HSGs. The higher the curve number, the higher is the runoff in heavy precipitation events. The CN maps for 1996 and 2011 (Figure 4) were developed using the ArcCN tool in the ArcGIS environment by overlaying the hydrological map with the land-use map and extracting the curve numbers for different combinations from an index table (Table 6).

The minimum runoff depth was obtained for dense forest $(2.52 \mathrm{~cm} /$ year in 1996 and $2.60 \mathrm{~cm} /$ year in 2011) and the maximum depth for bare land $(14.10 \mathrm{~cm} /$ year in 1996 and $14.50 \mathrm{~cm} /$ year in 2011). Runoff depth was high also for residential land and second-grade range (Figure 5a). In bare land, the annual runoff was slightly over $20 \%$ of the annual precipitation, whereas the percentage was around $4 \%$ in dense forest. This was in line with earlier research, which has shown the strong impact of vegetation on water runoff $[2,34,36]$.

The highest runoff volumes in both years were obtained for bare land, second-grade rangeland, and rangeland with dry farming (Figure $5 b$ ), whereas sparse forest and horticulture, dense forest, irrigated farming, and residential areas had the lowest runoff volumes.

The total runoff volume was 223.31 mill. $\mathrm{m}^{3}$ in 1996 (8.3\% of precipitation) and 243.35 mill. $\mathrm{m}^{3}$ in $2011\left(9.0 \%\right.$ of precipitation). It increased by 20.05 mill. $\mathrm{m}^{3}(8.98 \%)$ during the 15 years. Most of the increase was related to the increased areas of bare land and rangeland with dry farming. Runoff decreased in first- and second-grade rangeland because the area of these land uses decreased. 
(a)

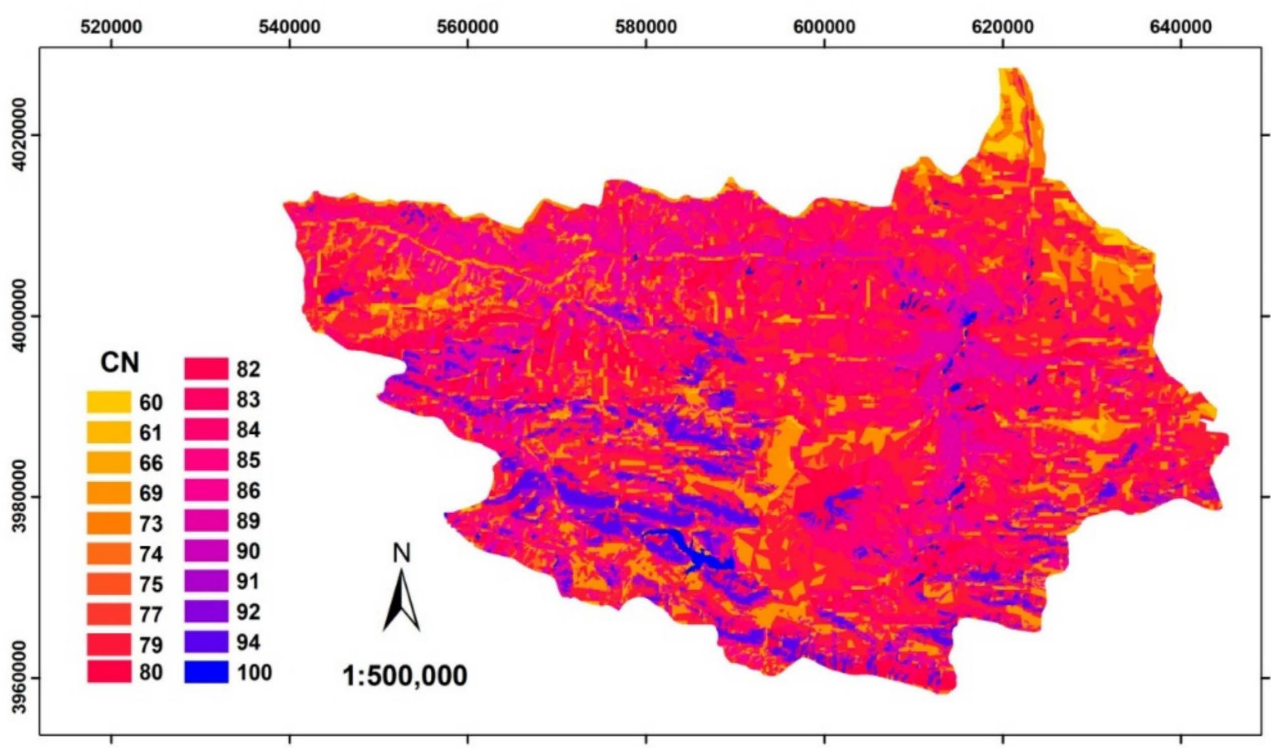

(b)

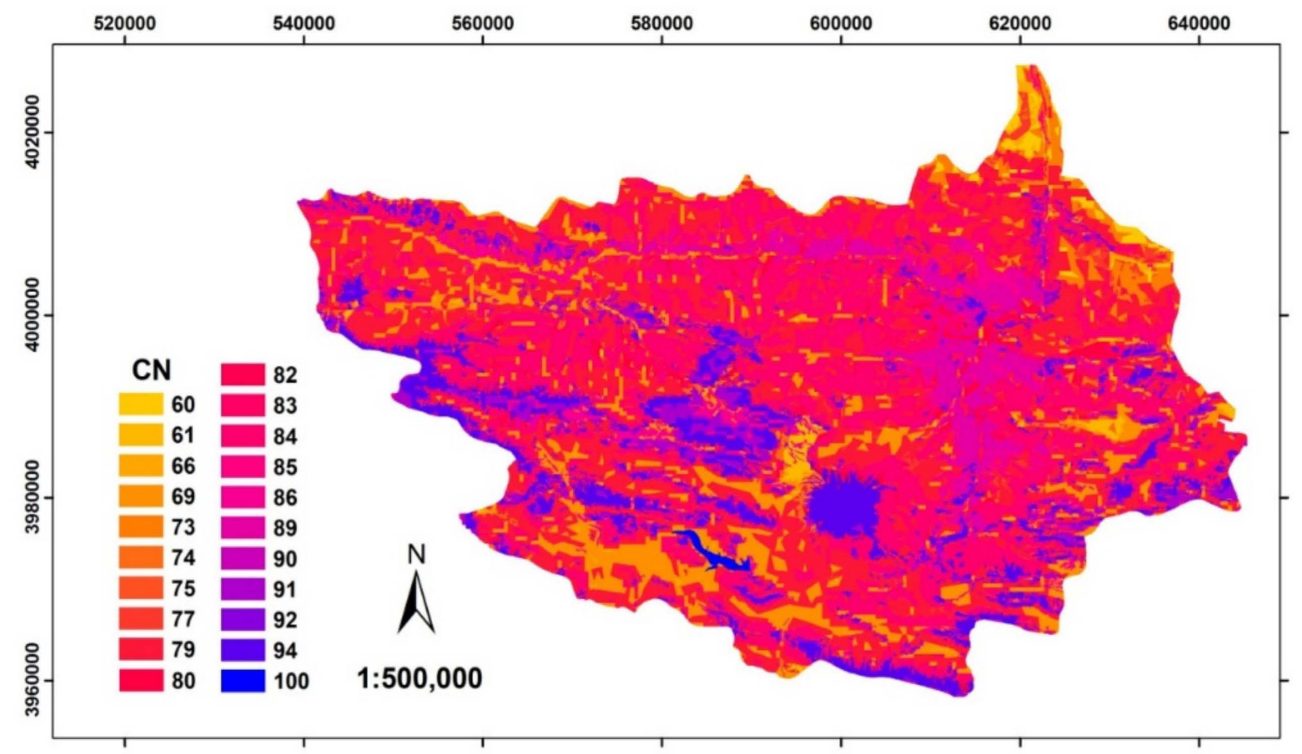

Figure 4. Curve number (CN) map of 1996 (a) and 2011 (b). 
(a)

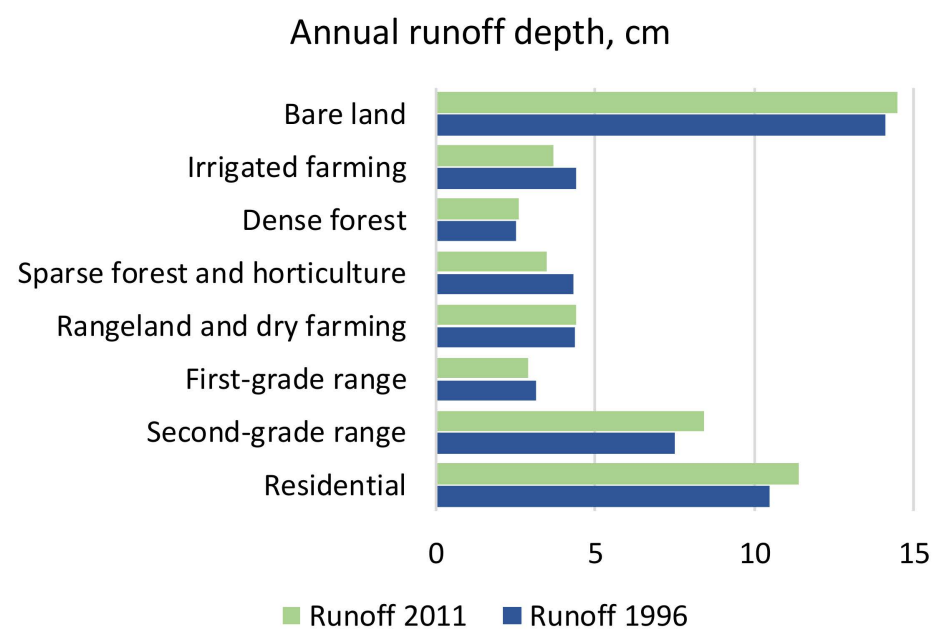

(b)

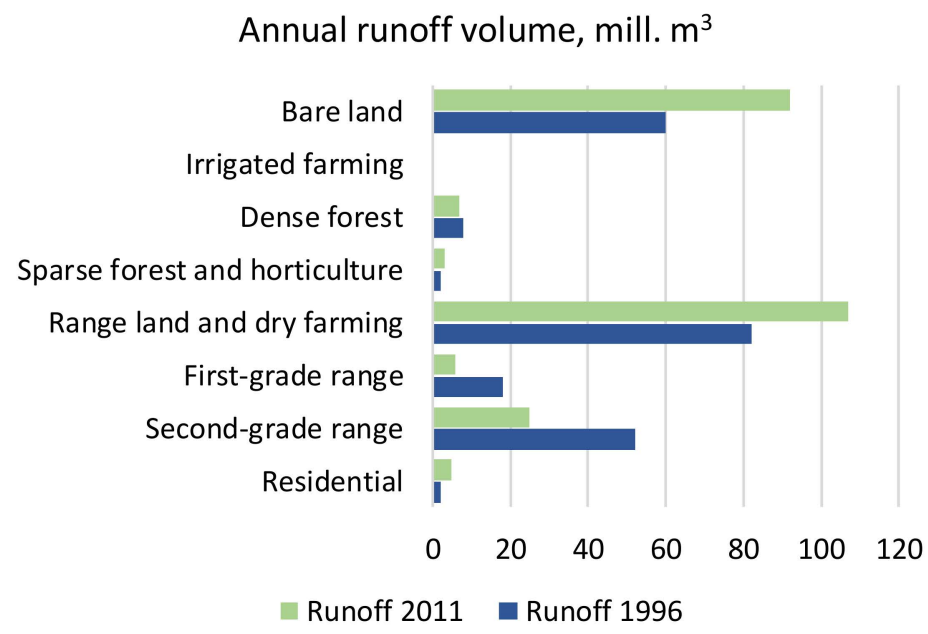

Figure 5. Mean annual runoff depths (a) and volumes (b) in different land-use classes in 1996 and 2011. Runoff depth is that part of annual precipitation $(66.5 \mathrm{~cm} /$ year $)$ that does not infiltrate the soil.

\section{Discussion}

This study used remote sensing to detect changes in land use and the SCS curve number method to calculate the effect of land-use change on water runoff. The runoff generation method is highly complex, nonlinear, dynamic in character, and affected by numerous interconnected physical factors. Similar methods have been used in the past $[29,44,45]$ and the approach has been deemed suitable for analyzing the effect of land use on hydrological processes $[10,21,44]$. In the current study, the trends of land-use changes and the Kappa statistics calculated for the classified Landsat images are consistent with the results of Mula-aghajanzadeh et al. [40]. The results indicated good accuracy, suggesting that Landsat imageries have high potential in land-use mapping and hydrological studies [21,29,37]. The use of remote sensing and GIS techniques in combination with hydrological models offers cost-effective analyses as compared with the conventional approaches discussed, for example, for example, Sajikumar and Reyma [18], Kumar et al. [21], and Al-Ghobari et al. [46].

The curve number method is widely used in several countries. Its advantages are simplicity, predictability, stability, a low number of parameters, and its responsiveness to major runoff-producing watershed properties such as soil type, land use, and surface condition $[21,28,44]$. The disadvantages include marked sensitivity to curve number, 
varying accuracy for different biomes, and the fixing of the initial abstraction ratio at 0.2 in Equation (2) [47].

D'Asaro and Grillone [48] suggested, according to recent studies, that the initial abstraction ratio should be 0.05 rather than 0.2 . Woodward et al. [49], using rain event and runoff data from several hundred plots, also found that a value of about 0.05 gave a better fit to the data and would be more appropriate than 0.2 in runoff calculations. Because of the above suggestions, we calculated the runoff results of our case study area also with the 0.05 initial abstraction ratio. The magnitude of the runoff volume did not change much. The 15-year increase in runoff volume was 14.68 mill. $\mathrm{m}^{3}(6.7 \%)$ instead of the 20.05 mill. $\mathrm{m}^{3}(8.98 \%)$ obtained with an initial abstraction ratio of 0.2 . The runoff depths and volumes of different land-use classes did not change much.

Huang et al. [50] found that the standard CN method could underestimate large runoff events and overestimate small events. They developed a correction equation based on the relationship between slope and the observed and theoretical $\mathrm{CN}$ values. Their improved method predicted runoff depths with an R2 of 0.822. Garen and Moore [51] mentioned that the use of the curve number method was appropriate for flood hydrograph engineering applications, but more physically based algorithms were needed for nonpoint source water quality modeling.

Our analyses ignored the fact that the $\mathrm{CN}$ depends on antecedent moisture conditions (AMC), which may change during the year [52]. This simplification was done because of insufficient data for generating temporal variation in $\mathrm{AMC}$ and $\mathrm{CN}$. However, calculations with different initial abstraction factors suggest that this simplification does not have any major impact on the main conclusions of the study.

The results of this study on runoff depth and runoff volume cannot be easily compared with previous research because of differences in the amount and distribution of precipitation, land uses, topography, and soil types [17]. In the calculation example of Zhan and Huang [29], the proportion of surface runoff was 3.8\% of precipitation, whereas it was about $9 \%$ in our study. In addition, Singh et al. [53] calculated that, in the Varekhadi River basin (India), the runoff after the heaviest rain events could be as much as $62-74 \%$ of precipitation.

Climate change may also affect water availability and surface runoff $[54,55]$. The surface runoff will increase if heavy rain events become more frequent. However, most changes can be traced back to human interferences with natural ecosystems. Il Eum et al. [56] and Yin et al. [55] also concluded that land-cover changes played a larger role in the trends of surface runoff than climate change.

In our case study area, land-use changes resulted in a 9\% increase in runoff volume during the 15 years. Most of the increase was related to the changes that occurred in rangeland, bare land, and residential land, which was in line with the results of Kamuju [57]. Most changes were caused by human activities, which increased the demand for natural resources and often represented exploitative and unsustainable use. Although the increase is significant, clearly higher increases have been reported in the literature [2].

\section{Conclusions}

The present study indicates that the SCS-CN method integrated with remote sensing and GIS techniques can be used effectively in watershed management. Large variations in runoff potential were observed for different land uses and landcover types. The results on the effect of land-use changes on surface runoff can be seen as a warning that should affect the future management of the Haraz River basin. As much as 38\% of the study area experienced land-use changes during 15 years, mostly in an unfavorable direction from a water runoff point of view. The trend observed in this study may continue in the future, leading to increasing environmental damage and loss of rangelands and forests in Hyrcania. Analyses of past land-use changes and predictions of future changes provide important information for land-use planning, to promote sustainable development and to conserve natural resources. Increasing the awareness of environmental problems through education 
and having local people participate in the planning and decision-making processes are necessary to prevent irreversible adverse land-use changes in the Hyrcania region.

Author Contributions: Conceptualization, L.R. and N.A.-S.; methodology, N.A.-S.; formal analysis, L.R.; investigation, L.R.; resources, N.A.-S.; data curation, L.R.; writing—original draft preparation, L.R.; writing-review and editing, N.A.-S. and T.P.; supervision, N.A.-S. and T.P. All authors have read and agreed to the published version of the manuscript.

Funding: This research received no external funding.

Data Availability Statement: The data of this study are available on request from the corresponding author.

Conflicts of Interest: The authors declare no conflict of interest.

\section{References}

1. Food and Agriculture Organization of the United Nations; United Nations Environment Programme. The Future of our Land. Facing the Challenge; FAO Publication, FAO: Rome, Italy, 1999; pp. 1-82.

2. Githui, F.; Mutua, F.; Bauwens, W. Estimating the impacts of land-cover change on runoff using the soil and water assessment tool (SWAT): Case study of Nzoia catchment, Kenya. Hydrol. Sci. J. 2010, 54, 898-908.

3. Singh, P.; Javed, S.; Shashtri, S.; Singh, R.P.; Vishwakarma, C.A.; Mukherjee, S. Influence of changes in watershed land-use pattern on the wetland of Sultanpur National Park, Haryana using remote sensing techniques and hydrochemical analysis. Remote Sens. Appl. Soc. Environ. 2017, 7, 84-92.

4. Bal, M.; Dandpat, A.K.; Naik, B. Hydrological modeling with respect to impact of land-use and land-cover change on the runoff dynamics in Budhabalanga river basing using ArcGIS and SWAT model. Remote Sens. Appl. Soc. Environ. 2021, $23,100527$. [CrossRef]

5. Mallikarjuna, V.; Prasad, K.R.K.; Udaya Bhaskar, P.; Sailakshmi, M. Watershed modeling of Krishna Delta using GIS and remote sensing techniques. Int. J. Eng. Sci. Technol. 2012, 4, 4539-4545.

6. Ibrahim, A.; Zakaria, N.; Harun, N.; Hashim, M.M.M. Rainfall runoff modeling for the basin in Bukit Kledang, Perak. In Proceedings of the IOP Conference Series: Materials Science and Engineering, Selangor, Malaysia, 17-19 November 2020; Volume 1106, p. 012033. [CrossRef]

7. Shang, X.; Jiang, X.; Jia, R.; Wei, C. Land-use and climate change effects on surface runoff variations in the upper Heihe River basin. Water 2019, 11, 344. [CrossRef]

8. Desta, Y.; Goitom, H.; Aregay, G. Investigation of runoff response to land-use/land-cover change on the case of Aynalem catchment, North of Ethiopia. J. Afr. Earth Sci. 2019, 153, 130-143. [CrossRef]

9. Xu, D.; Lyon, S.W.; Mao, J.; Dai, H.; Jarsjö, J. Impacts of multi-purpose reservoir construction, land-use change and climate change on runoff characteristics in the Poyang Lake basin, China. J. Hydrol. Reg. Stud. 2020, 29, 100694. [CrossRef]

10. Yin, J.; He, F.; Xiong, Y.J.; Qiu, G.Y. Effect of land-use/land-cover and climate changes on surface runoff in a semi-humid and semi-arid transition zone in Northwest China. Hydrol. Earth Syst. Sci. 2017, 21, 183-196. [CrossRef]

11. Selkimäki, M.; Gonzaléz-Olabarria, J.R.; Pukkala, T. Site and stand characteristics related to surface erosion occurrence in forests of Catalonia (Spain). Eur. J. For. Res. 2012, 131, 727-738. [CrossRef]

12. De Jong, C. European perspectives on forest hydrology. Forest Hydrology: Processes, Management and Assessment, 1st ed.; CABI: Wallingford, UK, 2016; pp. 69-87.

13. Faccini, F.; Luino, F.; Paliaga, G.; Sacchini, A.; Turconi, L.; de Jong, C. Role of rainfall intensity and urban sprawl in the 2014 flash flood in Genoa City, Bisagno catchment (Liguria, Italy). Appl. Geogr. 2018, 98, 224-241. [CrossRef]

14. Kastridis, A.; Theodosiou, G.; Fotiadis, G. Investigation of Flood Management and Mitigation Measures in Ungauged NATURA Protected Watersheds. Hydrology 2021, 8, 170. [CrossRef]

15. Zhao, B.; Zhang, L.; Xia, Z.; Xu, W.; Xia, L.; Liang, Y.; Xia, D. Effects of rainfall intensity and vegetation cover on erosion characteristics of a soil containing rock fragments slope. Adv. Civ. Eng. 2019, 2019, 7043428. [CrossRef]

16. He, Y.; Lin, K.; Chen, X. Effect of land-use and climate change on runoff in the Dongjiang Basin of South China. Math. Probl. Eng. 2013, 2013, 471429. [CrossRef]

17. Liu, Z.; Yao, Z.; Huang, H.; Wu, S.; Liu, G. Land-use and climate changes and their impacts on runoff in Yarlung Zangbo river basin, China. Land Degrad. Dev. 2012, 25, 203-215. [CrossRef]

18. Sajikumar, N.; Remya, R.S. Impact of land-cover and land-use change on runoff characteristics. J. Environ. Manag. 2015, 161, 460-468. [CrossRef]

19. Shrestha, S.; Bhatta, B.; Shrestha, M.; Shrestha, P.K. Integrated assessment of the climate and land-use change impact on hydrology and water quality in the Songkhram River Basin, Thailand. Sci. Total Environ. 2018, 643, 1610-1622. [CrossRef]

20. Pandey, A.; Chowdary, V.M.; Mal, B.C.; Dabral, P.P. Estimation of runoff for agricultural watershed using SCS curve number and Geographic Information System. In Proceedings of the Map India Conference, New Delhi, India, 28-31 January 2003. 
21. Kumar, A.; Kanga, S.; Taloor, A.K.; Singh, S.K.; Đurin, B. Surface runoff estimation of Sind river basin using integrated SCS-CN and GIS techniques. HydroResearch 2021, 4, 61-74. [CrossRef]

22. Jaiswal, R.K.; Ali, S.; Bharti, B. Comparative evaluation of conceptual and physical rainfall-runoff models. Appl. Water Sci. 2020, 10, 48. [CrossRef]

23. Roy, T.; Gupta, H.V.; Serrat-Capdevila, A.; Valdes, J.B. Using satellite-based evapotranspiration estimates to improve the structure of a simple conceptual rainfall-runoff model. Hydrol. Earth Syst. Sci. 2017, 21, 879-896. [CrossRef]

24. Rozos, E. A methodology for simple and fast stream flow modelling. Hydrol. Sci. J. 2020, 65, 1084-1095. [CrossRef]

25. Rozos, E.; Dimitriadis, P.; Bellos, V. Machine Learning in Assessing the Performance of Hydrological Models. Hydrology 2022, 9, 5. [CrossRef]

26. Najafi Kalyani, N.; Ranjbar-Fordoei, A.; Fatemeh, P.; Musavi, H. Prediction of Soil Hydrological Responses under Land Use/Cover Changes using Markov Chains in Jiroft Watershed, Iran. ECOPERSIA 2022, 10, 47-59.

27. Ranjbar, H.; Gharehhassanloo, S. Modeling and Estimating the Potential of Runoff Using SCS Approach in GIS context (Case Study: Shahed Shahriar City). J. Environ. Sci. Stud. 2020, 5, 3002-3011.

28. Hu, S.; Fan, Y.; Zhang, T. Assessing the effect of land-use change on surface runoff in a rapidly urbanized city: A case study of the central area of Beijing. Land 2020, 9, 17. [CrossRef]

29. Zhan, X.; Huang, M.L. ArcCN-Runoff: An ArcGIS tool for generating curve number and runoff maps. Environ. Modeling Softw. 2004, 19, 875-879. [CrossRef]

30. Fang, F.N.; Hua, Z.H.; Lu, L.; Zhong, L.; Qian, J.; Lei, A. The effects of rainfall regimes and land-use changes on runoff and soil loss in a small mountainous watershed. Catena 2012, 99, 1-8. [CrossRef]

31. Pandey, A.C.; Singh, S.K.; Nathawat, M.S.; Saha, D. Assessment of surface and subsurface waterlogging, water level fluctuations, and lithological variations for evaluating groundwater resources in Ganga Plains. Int. J. Digit. Earth 2013, 6, 276-296. [CrossRef]

32. Singh, S.K.; Pandey, A.C.; Rathore, V.S.; Nathawat, M.S. Evaluating factors responsible for contrasting signature of wasteland development in northern and southern Ganga Plains (Bihar State, India) with focus on waterlogging. Arab. J. Geosci. 2014, 7, 4175-4190. [CrossRef]

33. Balkhair, K.S.; Ur Rahman, K. Development and assessment of rainwater harvesting suitability map using analytical hierarchy process, GIS and RS techniques. Geocarto Int. 2021, 36, 421-448. [CrossRef]

34. Patil, N.S.; Nataraja, M. Effect of land-use/land-cover changes on runoff using hydrological model: A case study in Hiranyakeshi watershed. Modeling Earth Syst. Environ. 2020, 6, 2345-2357. [CrossRef]

35. Rana, V.K.; Suryanarayana, T.M.V. GIS-based multi criteria decision making method to identify potential runoff storage zones within watershed. Ann. GIS 2020, 26, 149-168. [CrossRef]

36. Coutu, G.W.; Vega, C. Impacts of land-use changes on runoff generation in the east branch of the Brandywine Creek watershed using a GIS-based hydrological model. Middle States Geogr. 2007, 40, 142-149.

37. Muttaqin, A. Estimation of peak runoff impact from land-use change using remote sensing and GIS in Keduang sub-watershed. In Proceedings of the IOP Conference Series: Earth and Environmental Science, virtual. 25 May 2021; Volume 824, p. 012005. [CrossRef]

38. Zurqani, H.A.; Post, C.J.; Mikhailova, E.A.; Schlautman, M.A.; Sharp, J.L. Geospatial analysis of land-use change in the Savannah River Basin using Google Earth Engine. Int. J. Appl. Earth Obs. Geoinf. 2018, 69, 175-185. [CrossRef]

39. Adhiambo, M.P.; Kironchi, G.; Mureithi, S.; Kathumo, V. Assessing land-use and land-cover change using participatory geographical information system (PGIS) approach in Nguruman Sub-catchment, Kajiado north Sub county, Kenya. J. Geogr. Reg. Plan. 2017, 10, 219-228.

40. Mola-aghajanzadeh, S.; Soleymani, K.; Habibnejad, M.; Kavyan, A.; Rahmani, M. Application of Remote Sensing in Assessing Land-Use Changes in Haraz Watershed. Geogr. Res. 2021, 36, 275-284.

41. NRCS. National Engineering Handbook, Part 630 Hydrology; USDA: Washington, DC, USA, 2009.

42. Abraham, S.; Huynh, C.; Vu, H. Classification of soils into hydrologic groups using machine learning. Data 2020, 5, 2. [CrossRef]

43. USACE. Hydrologic Modeling System HEC-HMS: Technical Reference Manual; Hydrologic Engineering Center, US Army Corps of Engineers: Davis, CA, USA, 2000; p. 138

44. Verma, S.; Singh, P.K.; Mishra, S.K.; Singh, V.P.; Singh, V.; Singh, A. Activation soil moisture accounting (ASMA) for runoff estimation using soil conservation service curve number (SCS-CN) method. J. Hydrol. 2020, 589, 125114. [CrossRef]

45. Babykalpana, Y.; Thanushkodi, K. Classification of land-use/land-cover change detection using remotely sensed data. Int. J. Comput. Sci. Eng. 2011, 3, 1638-1644.

46. Al-Ghobari, H.; Dewidar, A.Z. Integrating GIS-Based MCDA Techniques and the SCS-CN Method for Identifying Potential Zones for Rainwater Harvesting in a Semi-Arid Area. Water 2021, 13, 704. [CrossRef]

47. Ponce, V.M.; Hawkins, R. Runoff curve number: Has it reached maturity. J. Hydrol. Eng. 1996, 1, 11-19. [CrossRef]

48. D'Asaro, F.; Grillone, G. Empirical investigation of curve number method parameters in the Mediterranean area. J. Hydrol. Eng. 2012, 17, 1141-1152. [CrossRef]

49. Woodward, D.E.; Hawkins, R.H.; Jiang, R.; Hjelmfelt, A.T., Jr.; Van Mullem, J.A.; Quan, Q.D. Runoff curve number method: Examination of the initial abstraction ratio. In Proceedings of the 2003 World Water \& Environmental Resources Congress, Philadelphia, PA, USA, 23-26 June 2003; American Society of Civil Engineers: Peston, VA, USA, 2003. [CrossRef] 
50. Huang, M.; Gallichand, J.; Wang, Z.; Goulet, M. A modification to the Soil Conservation Service curve number method for steep slopes in the Loess Plateau of China. Hydrol. Processes 2006, 20, 579-589. [CrossRef]

51. Garen, D.C.; Moore, D.S. Curve number hydrology in water quality modelling: Uses, abuses, and future directions. J. Am. Water Resour. Assoc. 2005, 41, 377-388. [CrossRef]

52. Chow, V.T.; Maidment, D.R.; Mays, L.W. Applied Hydrology; McGraw-Hill: New York, NY, USA, 1988; p. 572. ISBN 007-010810-2.

53. Singh, A.K.; Sharma, S.B.; Jain, A.O. Mapping and Prediction of Surface Run-off using SCS-CN Method. In Proceedings of the Geomatics 2011, National Conference on Impact of Climate Chang with Special Emphasis on Desertification, Ajmer, India, 3-5 February 2011.

54. He, Y.; Song, J.; Hu, Y.; Tu, X.; Zhao, Y. Impacts of different weather conditions and land-use change on runoff variations in the Beiluo River Watershed, China. Sustain. Cities Soc. 2019, 50, 101674. [CrossRef]

55. Yin, J.; He, F. Researching relationship between the change of vegetation cover and runoff based on RS and GIS. Procedia Environ. Sci. 2012, 12, 1077-1081.

56. Il Euma, H.; Dibikeb, Y.; Prowse, T. Comparative evaluation of the effects of climate and land-cover changes on hydrologic responses of the Muskeg River. J. Hydrol. Reg. Stud. 2016, 8, 198-221. [CrossRef]

57. Kamuju, N. Rainfall-runoff estimation and comparative analysis using advanced geospatial digital hydrological modelling tools, ArcCN-Runoff \& ArcSWAT. Int. J. Geoinformatics Geol. Sci. 2015, 2, 1-6. 